第51回大会キーノートレクチャー：運動生理学

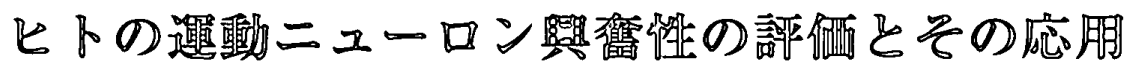

\author{
船㖽広三 \\ New approach for evalluation of spimal motomeun om pool excitabillity \\ amd its application
}

\section{Kozo Funase}

(Japam J. Phys. Edusc. IHIth. Spont Sci. 46: 597-605, November, 2001)

キーワード：H反射，M波，運動ニューロン，興 繁性，痙性、シナプス前抑制

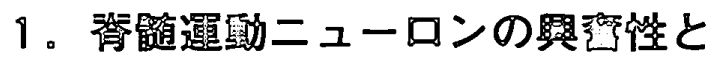 Moffimann 厚射}

随意運動にせよ反射にせよ，ある筋が収縮して 運動が生じるためには，その筋を直接的に支配し ている脊随運動ニューロン（motoneuron：MN) が興奮して活動電位が発生し, 筋に伝えられる必 要がある.MNの膜電位が閾值に達せず活動電位 が発生しない状態であっても, 膜電位レベルによ っては, 付加されるシナブス入力によって闘值に 達するか否か，すなわち $\mathrm{MN}$ の與奮しやすさ（興 奮性）は異なったものになると考えられる。ヒ卜 に扔いてMNの興奮性を探る方法に Hoffmann 反 射（H反射）がある（図 $1 \mathrm{~A}$ ). H反射は, 伸張反 射回路の入力線維である筋紡錘 1 次終末から発す るIa線維を選択的に電気刺激することによる生じ る. H反射の振幅の変化は，ある筋を支配する $\mathrm{MN}$ プールに含まれる MNの膜電位の変化に伴って発

長筒大学医学部保健学科 于 852-8520 長䗁市坂本 1-7-1

連路先 船前広三
火する $\mathrm{MN}$ 数の増減を反映しており,これを $\mathrm{MN}$ プールの與奮性の指標として, 脊檤反射機構なら びに随意運動と脊面反射機構のかかわりに関する 研究が幅広く行われている38,41).MNプール興奮 性自体に影響を及ほす要因については, 運動経 験4,33)，環境24.44，疾患2.1230.34) などの報告があるが， 用いられているMNプール與奮性の個人差を評価 するための指標自体に方法上・解釈上の問題があ ることが指摘されている37,40). したがって，MNプ ール興奮性の評価のためのより適切な指標を考案 する必要がある，本稿では，MNプール興奮性の 評価のための新たな指標, およびそのリハビリテ ーション分野や身体運動科学分野への応用に関す る我々の研究成果について概説する.

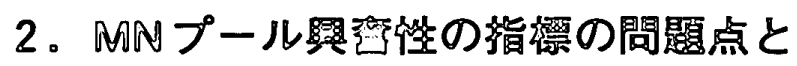
新た楷標

最もよく用いられているMNプール與奮性の指 標は, $\mathrm{M}$ 波の最大值（Mmax）に対する $\mathrm{H}$ 反射の 最大值（Hmax）の比（Hmax/Mmax）である（図

School of Health Sciences, Nagasaki University 852-8520

Corresponding author funase@net. nagasaki-u.ac.jp 
1 B). Mmaxは，ある筋の MN プールを構成する MNの軸索である $a$ 運動線維のすべてが刺激され ることを意味し，これはプール内の MNすべてが 発火した場合の筋電位に相当することになる．し たがって Hmax/MmaxはMNプール内において Ia 入力によって反射性に発火する MNの割合を示す ことになる.しかし， M波の発生に伴って，活動 電位が $a$ 運動線維上を逆行性に伝導し，順行性に 伝導してくる $\mathrm{H}$ 反射のための活動電位との間で衝 笑による閉塞現象が生じることから（図 $1 \mathrm{~A}$ )，見 かけ上の Hmaxが必ずしも Ia入力によって反射性 に発火するすべての MNを示していることにはな らない。この点は, 個人間の $\mathrm{MN}$ プール興奮性の 比較においては大きな問題となる.

MN プールの興奮性が高まっていれば，より弱 い刺激強度で $\mathrm{H}$ 反射が出現すると考えられるため, $\mathrm{M}$ 波の閾值（Mth）に対する $\mathrm{H}$ 反射の閥值（Hth） の比（Hth/Mth）もMNプール興奮性の指標とし て用いられている (図 1 B)。しかし，Hth/Mthの 值を決定する要因がMNプールの興奮性の高低だ けであるとはいい難い.Ia線維と $a$ 運動線維の電 気刺激に対する発火間値の差異なども Hth/Mth を 決定する要因の一つであると考えられる。また， $\mathrm{H}$ 反射の大きさに依存した条件刺激効果量の違い

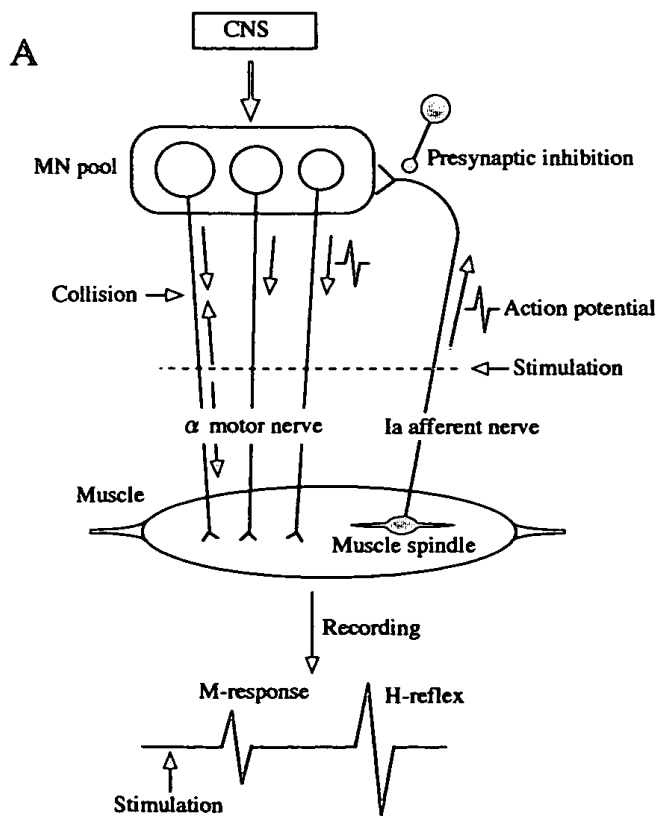

が指摘されている9, 13, 16, 28). すなわち, $\mathrm{H}$ 反射の振 幅が小さい場合，すなわち $\mathrm{H}$ 反射の閥值付近では， もたらされる条件刺激効果量もごく僅かなもので あることになる。これは，そもそも Hth/Mthが MNプールの興奮性の高低に依存した変化を示し にくいのではないかという疑義をもたらすもので ある14).

このようにここれま゙ $\mathrm{MN}$ プール興奮性の指標 として用いられてきた Hmax/Mmaxや Hth/Mth は，それぞれに方法上・解釈上の問題を有してお り，MN プール興奮性を評価するための適切な指 標は，未だ不十分であると言わざるを得ない状況 である．筆者らは，従来用いられてきたMNプー ル興奮性の指標の持つ問題点を克服する可能性を 示す新たな指標として, M 波の増加率（Mslp）に 対する Mth 以下の刺激強度における $\mathrm{H}$ 反射の増加 率（Hslp）の比（Hslp/Mslp）についての報告を 行っている ${ }^{15,17,23)}$ (図 1 B).

Mslpは $a$ 運動線維束への刺激強度増大に伴って 順次動員されることによる運動単位数の増加率と 考えられる.Mslpは刺激強度増大による $a$ 運動線 維動員数の増加率を表しているが，神経線維の刺 激闘值は直径の大きい（太い）ものほど低いので, Mslpを構成するMNの動員順序としては低閾値の 太い $a$ 運動線維から順次発火することになる。こ れは明らかに単シナプス反射弓に含まれる非反射

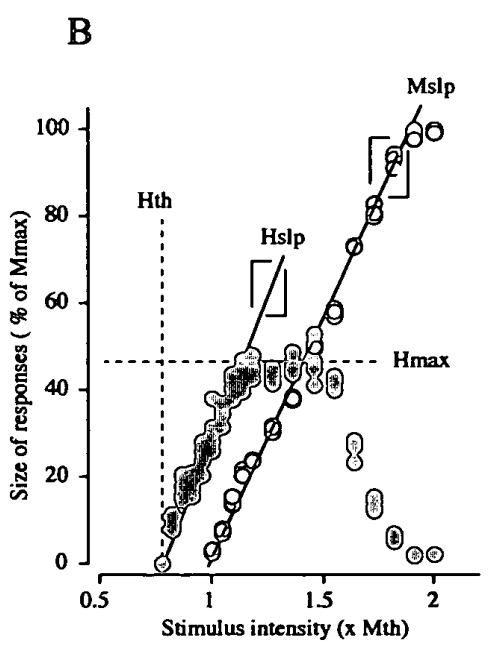

図 $1 \mathrm{~A}$ ：H反射と $\mathrm{M}$ 波の誘発原理と神経回路を示す模式図. MN は運動ニューロン, CNSは中枢神経系を表す． B ：H 反射（○) とM波（O）のリクルートメントカーブの1例. 
成分である。一方，HslpはIa 線維への刺激増加に 伴って順次動員されるIa 入力の増加によって発火 する運動ニューロン数の増加率と考えられ，これ は単シナプス反射弓に含まれる反射成分を表して いる. したがって，Mslpと Hslpの比は単シナプ ス反射弓を構成する非反射成分に対する反射成分 の割合を表していると考えられる．Mslpは刺激強 度増大による $a$ 運動線維動員数の増加率を表して いるが，神経線維の刺激閥值は直径の大きい（太 い）ものほど低いので，Mslpを構成する MNの動 員順序としては低闇值の太い $a$ 運動線維から順次 発火することになる，一方，HslpはIa線維に対す る刺激増大に伴って順次発火する $\mathrm{MN}$ の増加率を 表すことになる．刺激部位では低閾値の太い Ia 線 維から発火することになるが，Ia線維はMN プー ル内のほほ総てのMNにシナプス結合していると 考えられているので ${ }^{29)}, \mathrm{MN}$ プールにおいてはサ イズの原理にしたがい，低閥値の小型の MNから 動員されることになる．小型の MNの軸索である $a$ 運動線維は大型の MNのそれに比較して細いと 考えられる．したがって，Mslpと Hslpでは動員 される運動単位の順序は逆になっていることが考 えられる。しかし，図１Bに示す様に，運動単位 の動員順序が逆であっても, Mslp と Hslpの変化 率を絶対值で見れば問題はない。また，Hslpは Mth 以下の刺激強度における変化であるので, M 波の発生に伴う活動電位の逆行性伝導による $\mathrm{H}$ 反 射の閉塞現象の影響は受けない.したがって，MN プール興奮性の比較，特に個人間比較についてそ の妥当性が示唆される.

\section{MNプール與琶㭫変化と Mslp/Mslpの閣係}

Hslp/Mslpが実際にMNプール興奮性の変化に 対応した変化を示すか否かを調べるために，H反 射導出筋であるヒラメ筋の拮抗筋収縮（背届）に よる相反抑制効果と同名筋収縮（底屈）による促 通効果を観察した ${ }^{15)}$. 背屈・底屈は等尺性収縮で 行い, 収縮強度は最大随意収縮の $10 \%$ 及び $20 \%$ とした，持続性背届時においては，主に拮抗筋側 からの相反抑制機構による抑制効果がヒラメ筋 MN
にもたらされるものと考えられる8.10.36.39). 一方， 軽度な持続性底屈時においては, 主にヒラメ筋 $\mathrm{MN}$ への随意指令による下行性入力や $a-\gamma$ 連関によ る筋紡錘からの末梢性入力などによってヒラメ筋 MNに対しては促通効果をもたらすものと考えら れる ${ }^{7313,35)}$. 安静時に比較して, Hslp/Mslpは足関 節背届時では収縮強度に応じて減少し，足関節底 屈時においては収縮強度に応じて増加した（図 2). このように，同一個人内においてはHslp/Mslpは MN プール興奮性の増減に依存した変化を示した.

\section{Hslp/RMs』pによる痙縮息渚の

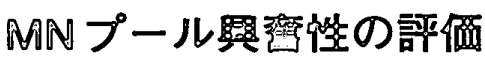

Hslp/Mslpは個人内において MNプール興偪性 の増隇に依存した変化を示した。次に個人間にお ける MN プール興傗性の比較に関する Hslp/Mslp の有用性を検証するために，健常者と痙縮患者の MN プール興窑性の差異について調べた。まず， 健常者群と脊䯣感染症である Human T-lymphotropic-virus-I-associated myelopathy (HAM) による痤縮患者群において MNプール興奮性の比 較を行った ${ }^{17)}$. 図 $3 \mathrm{~A}$ に健常者と痓縮患者の $\mathrm{H}$ 反 射と $\mathrm{M}$ 波のリクルートメントカーブの例，及び計 測されたHmax/Mmax, Hth/Mth, Hslp/Mslpの 值を示した，痙縮患者における $\mathrm{Hmax} / \mathrm{Mmax}$ Hth/Mthについては多くの報告がなされている が，健常者群と比較して必ずしも有意な差異を示 さないという報告もあり㖟昧な結果となってい

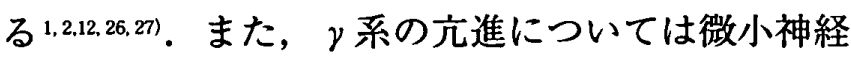
電図による解析から健常者との間に差異はないと の報告があり，むしろ否定的である ${ }^{3.22)}$. 伸張反射 六進の機序から考えて，健常者群に比べて痤縮患 者群の MN プール興隹性が高まっていることは十 分考えられるところである ${ }^{42)}$. しかしながら，そ のことが必ずしも示されない理由の 1 つとして， 指標自体の問題による可能性が考えられる. 図 3 Bには 28 名の健常者群と 6 名の痙縮患者群におけ る Hmax/Mmax, Hth/Mth, Hslp/Mslpの比較を 示した. $\mathrm{Hmax} / \mathrm{Mmax} や \mathrm{Hth} / \mathrm{M}$ th に比較して Hslp/Mslpは健常者に比べて氫縮患者の方が明ら かに低い危険率をもって有意に増加した。した 
A
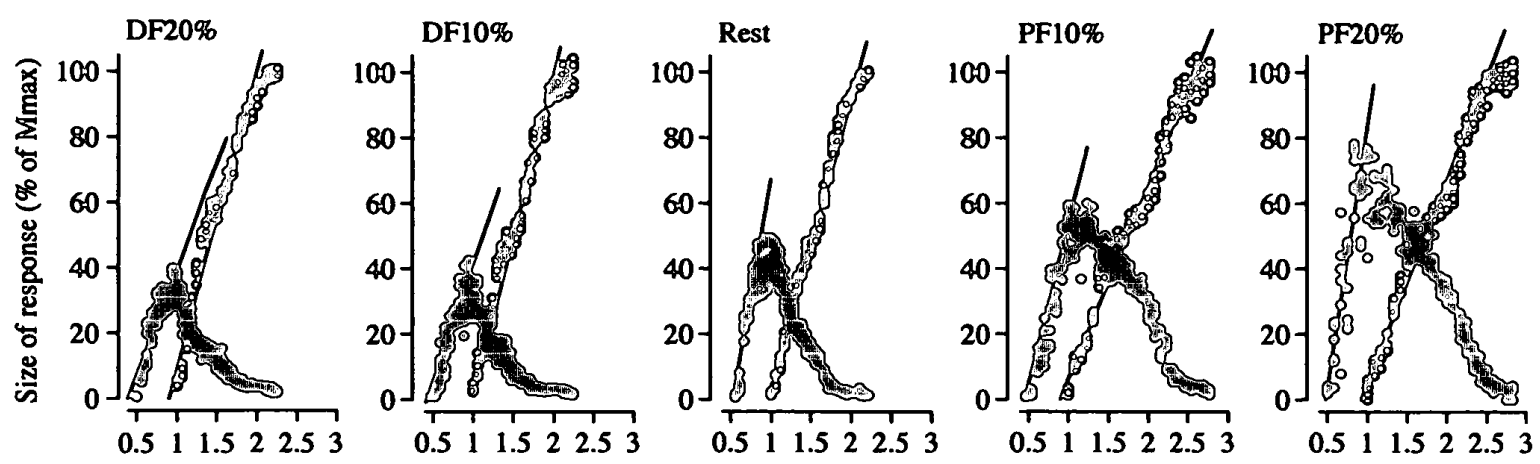

Stimulus intensity ( $x$ Mth)

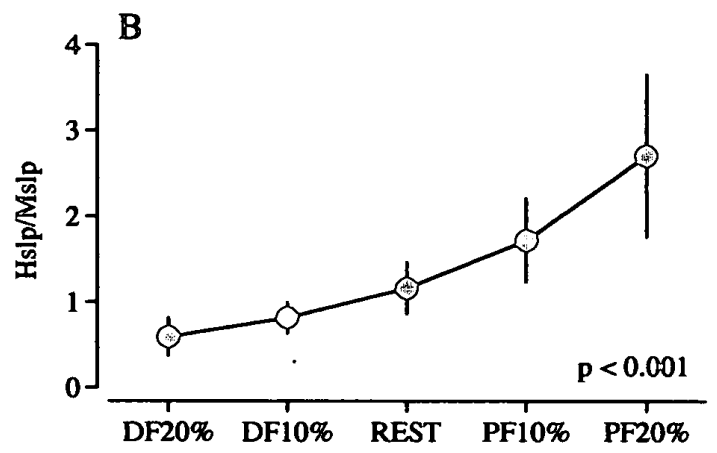

図 $2 \mathrm{~A}$ : 足関節背屈時 (DF), 安静時（REST）及び底屈時における $\mathrm{H}$ 反射 (O) と $\mathrm{M}$ 波 (O) のリクルートメントカー ブの変化と Hslp/Mslpの変化. 収縮強度は，背屈・底屈とも最大随意収縮に対して $10 \%$ 及び $20 \%$ 強度. B：5名の 被験者での結果.
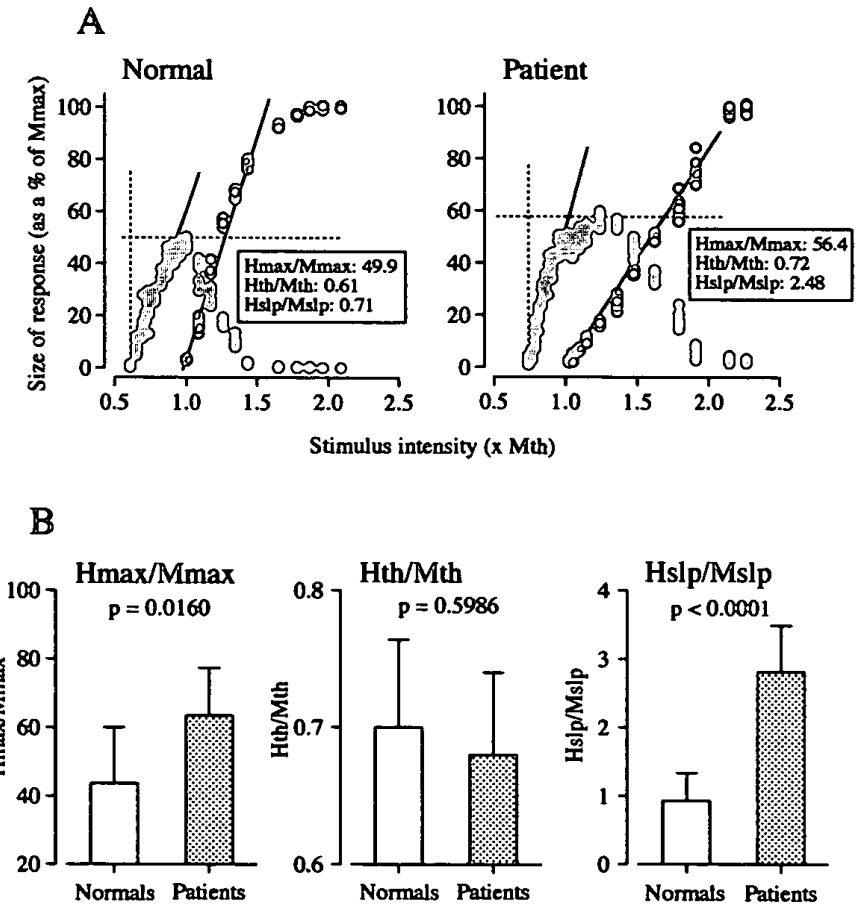

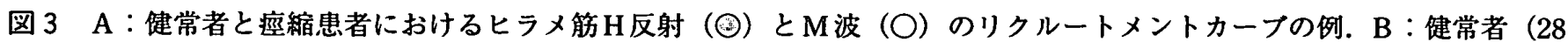
名）と痓縮患者群（6 名）における Hmax/Mmax, Hth/Mth, Hslp/Mslpの比較. 
がって，Hslp/Mslpを指標にしたMNプールの與 滀性の評価は，痙縮の客観的評価には有用である ことになる。

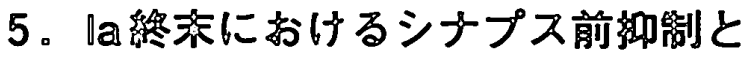 MN プール與得谈の閣偪}

それでは，どのような機序がMNプール興奮性 の高低を生み出す要因になっているのであろうか. Wolpawらは，オペラント条件付けによって学習 したサルにおいて単シナプス伸張反射振幅が変化 することを報告し，脊儎での “memory trace” の メカニズムについて Ia 終末におけるシナプス前抑 制の関与を示唆している ${ }^{45)}$ とトにおいても Nielsen らは長期にわたる運動によって MN プール 興奮性に変化が生じ，しかも実施する運動の夕イ プによって，その変化も異なることを報告し ${ }^{33)}$, その背景となるメカニズムにIa終末におけるシナ プス前抑制の関与を示唆している。また，伸張

反射方進が見られる痤縮患者においては，Ia終 末におけるシナプス前抑制が減弱していることが 報告されている ${ }^{11.30)}$. そこで, MNプール興奮性 と Ia終末におけるシナプス前抑制との関係につい て検討した ${ }^{19}$.

\section{A}

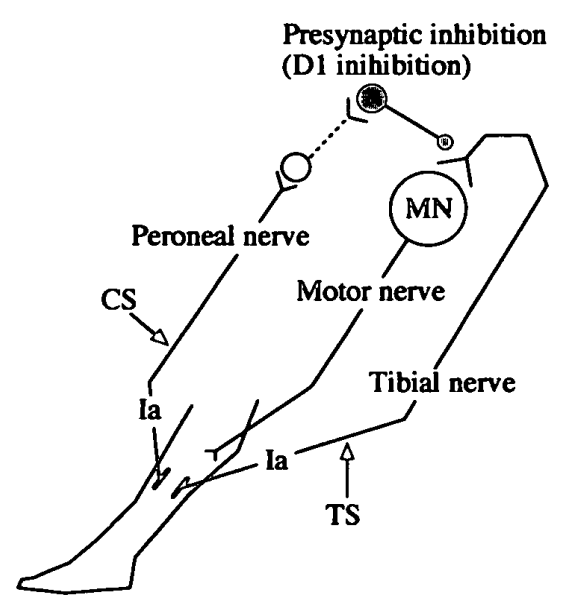

D1 抑制は腓骨神経への条件刺激に応じてヒラメ 筋 $\mathrm{H}$ 反射に $7 \sim 10 \mathrm{~ms}$ の潜時で出現し，20〜30ms で最大に達し, 以後 $100 \mathrm{~ms}$ にかけて減衰していく 抑制である。この時間経過はネコの脊䯣で観察さ れたシナプス前抑制の時間経過とよく一致してお り，その閾值は $\mathrm{M}$ 波の閾値以下, 最大効果は $\mathrm{M}$ 波 の閥值の 1.5 倍以下程度の強度で観察される。 し たがって明らかにI 群線維に起因した抑制である. また，刺激電極近傍の皮局刺激はこの抑制に効果 を持たない，以上のことから，D1 抑制はIa 終末に おけるシナプス抑制によるものであることが結論 づけられた ${ }^{32,39)}$. 図 4 にD1 抑制の神経回路を示す 模式図（A）と1名の被験者から記録したD1 抑制 の記録例（B）を示した。

条件刺激強度が強くなるにしたがって，D1 抑制 に続くD2 抑制と呼ばれる強力な抑制効果が見ら れる。これは腓骨神経への条件刺激による前脛骨 筋収縮によって他動的に伸張されたヒラメ筋から の筋紡錘入力の变化による 2 次的な抑制効果と考 えられている，したがって，条件刺激強度が強く なるに連れて D2 抑制は著明に大きくなる，一方， D1 抑制は条件刺激強度が強くなるにしたがって飽 和し，潜時的 $20 \mathrm{~ms}$ でほほ最大值を示している。こ

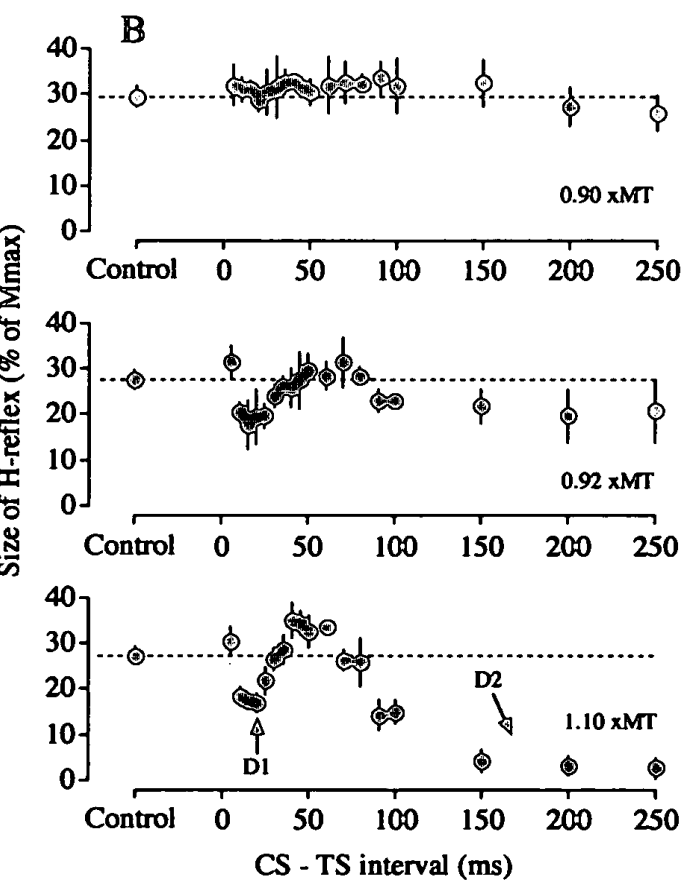

図 $4 \mathrm{~A}$ ：腓骨神経への条件刺激（CS）によって誘発されるD1抑制の神経回路を示す模式図. TSは試験制激を表す。B：

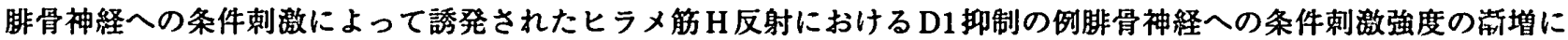

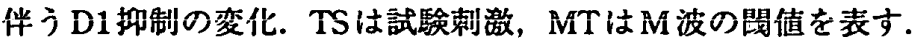


れらの特徴は報告された D1 抑制の特徴と一致し ている.

そこで，8名の被験者において， $\mathrm{M}$ 波の閾値の 1.08〜 1.12 の範囲で腓骨神経を条件刺激し, 潜時 $20 \mathrm{~ms}$ におけるヒラメ筋 $\mathrm{H}$ 反射の抑制量を D1 抑制 の最大值とし, 同時にこれらの被験者の Hslp/Mslp を測定して，個々の被験者の D1 抑制量と Hslp/ $\mathrm{Mslp}$ の関係を調べた（図 5 ）。試験 $\mathrm{H}$ 反射の大き さは最大 $\mathrm{M}$ 波の 25〜30\%の範囲になるように刺 激強度を調節した。その結果, Hslp/Mslpが低い （MN プール興奮性が低い）被験者は D1 抑制量は 大きく，逆にHslp/Mslpが高い（MNプール興奮 性が高い）被験者はD1抑制量が小さくなった。つ まり，Ia終末部におけるシナプス前抑制が MNプ ール興奮性の個人差を生み出す要因の 1 つになっ ていることが示唆された。

Ia終末部におけるシナプス前抑制に関する最近 の研究では, 姿勢や運動課題の違いに依存して上 位中枢がIa シナプス前抑制をもたらす介在ニュー ロンを介して MNに対するIa入力を下行性に調整 していることが報告されている5,6,25)。また，立位 時と座位時でのヒラメ筋 $\mathrm{H}$ 反射に関する我々の実 験結果においても, 背景 EMGが出現していない 状態, すなわち筋感覚入力が減少している状態で も，座位時に比べ立位時では $\mathrm{H}$ 反射は著名に抑制 されることが観察されている ${ }^{20)}$.したがって，こ
の介在ニューロンの活動は下行性入力の影響を強 く受けていると考えられる。

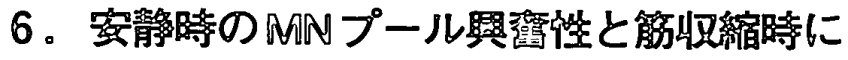

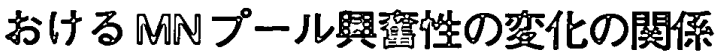

個人間において MNプール興奮性を比較する場 合にはHmas/MmaxやHth/Mthより Hslp/Mslp を用いた方が適切であることが示されたことを受 けて，個々の被験者の $\mathrm{MN}$ プール興奮性を Hslp/Mslpを用いて評価した上で，そのMNプー ル興奮性と新たに付加された条件による MN プー ル興奮性の変化との間に何らかの関係があるか否 かを，ヒラメ筋 MNプールに対する拮抗筋収縮に よる相反抑制効果から調べた ${ }^{18)}$ 。ここで言う相反 抑制効果とは，相反性 Ia 抑制機構を中心にしたシ ナプス前抑制機構を含む複数の脊髄反射機構の統 合された結果として被験筋 MN プール興奮性に反 映される最終出力としての相反抑制効果のことで ある. 図 $6 \mathrm{~A} に 28$ 名の健常者の MN プール興奮性 と足関節背屈時のヒラメ筋 $\mathrm{MN}$ プール興奮性の変 化の関係を示した，付加した条件は，それぞれ最 大随意収縮の $10 \% ， 30 \%$ の収縮強度である。 た，試験 $\mathrm{H}$ 反射の大きさに依存した条件付加時の 変化量の違いを除くために，試験 $\mathrm{H}$ 反射の大きさ

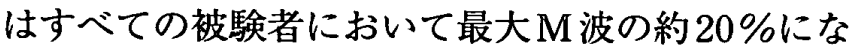
るように調節した，個々の被験者における試験 $\mathrm{H}$
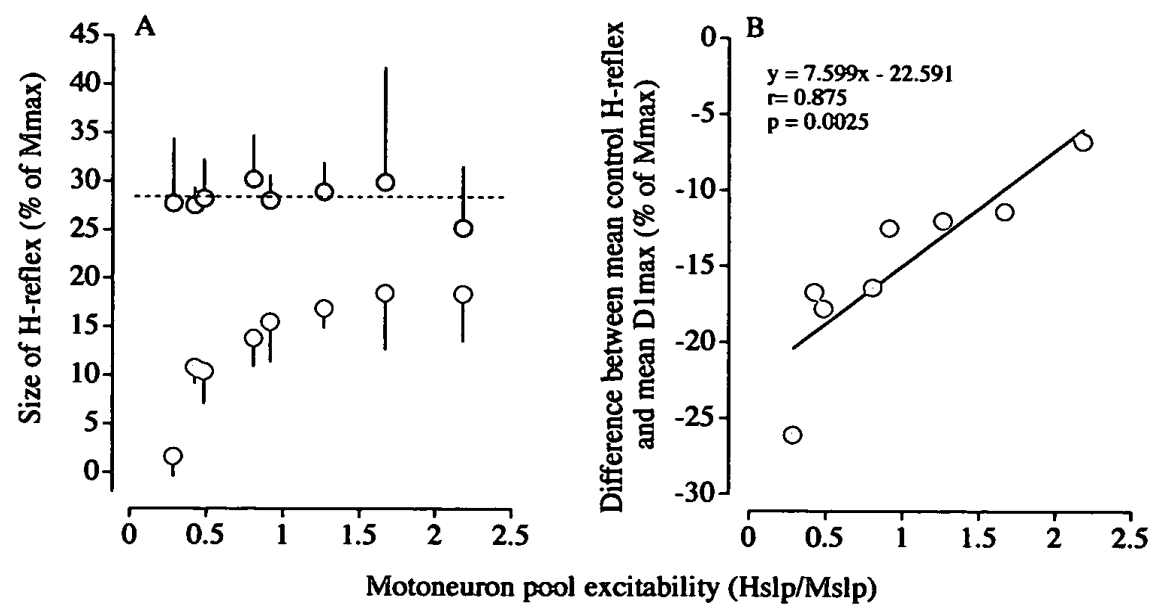

図 5A：8名の被験者におけるD1抑制によるヒラメ筋 $\mathrm{H}$ 反射の抑制と Hslp/Mslpの関係. 波線は試験 $\mathrm{H}$ 反射の平均値を

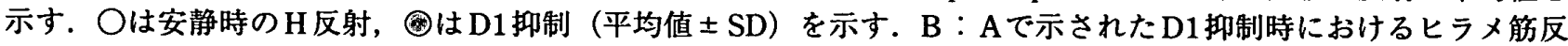
射の正味の抑制量と Hslp/Mslpの関係. 
反射と背屈時における正味の抑制量を見るために， それぞれの差を求め図 $6 \mathrm{~B}$ に示した。収縮強度が 30\%まではHslp/Mslpが低いほど，背屈による抑 制効果が大きいことが見てとれる.いずれにして も，個人間における Hslp/Mslp，すなわちMNプ ール與奮性の違いが，一定の条件を付加した場合 の $\mathrm{H}$ 反射の振幅変化の程度に影響を与えているよ うである，言い換えれば，随意運動によって新た な入力が MN プールに加重され MN プール興奮性 が変化する場合，その変化量には，随意運動を行 っていない状況での MN プール興蓄性の違いが影 響していることになる．MNに対するIa入力にシ ナプス前抑制をもたらす脊髄介在ニューロンには， 協同筋や拮抗筋からの I 群線維入力のみならず， 上位中枢からの下行性入力があることが知られて おり ${ }^{21.43)}$, 最近の研究では, 姿勢や運動課題の違 いに依存して上位中枢がこの介在ニューロンを介 してMNに対するIa入力を下行性に調整している ことが報告されている ${ }^{5.6 .25)}$ ．立位時と座位時での ヒラメ筋 $\mathrm{H}$ 反射に関する我々の実験結果において

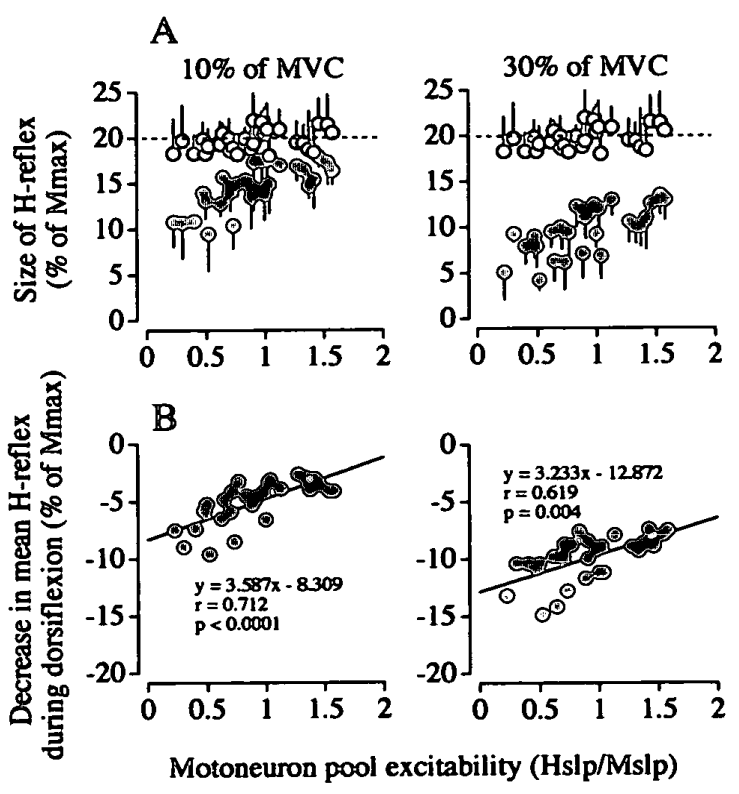

図 $6 \mathrm{~A}$ : 足関節背屈時 $(10 \%, 30 \%)$ における個々の被 験者のヒラメ筋反射の抑制量と Hslp/Mslpの関係. 収縮強度はいずれも最大随意収縮强度に対する\%強 度. Oは安静時の $\mathrm{H}$ 反射, ○は背屈時の $\mathrm{H}$ 反射（平 均值 $\pm \mathrm{SD}$ ）を示す. 被験者数は28名. 波線は安静 時 $\mathrm{H}$ 反射の平均值を示す，B：Aで示された足関節 背屈時におけるヒラメ筋 $\mathrm{H}$ 反射の正味の抑制是と Hsip/Mslpの関係.
も，背景EMGが出現していない状態，すなわち 筋感覚入力が減少している状態でも，座位時に比 べ立位時では $\mathrm{H}$ 反射は著名に抑制されることが観 察されている，併せて，本研究で示されたD1抑 制効果の結果，すなわち，運動遂行中でなくても Ia 終末におけるシナプス前抑制に依存した $\mathrm{H}$ 反射 の抑制量に個人差が観察されることなどから，こ の介在ニューロンの活動は運動時のみならず，安 静時においても随時下行性入力の影響下にあるこ とが示唆される。

本稿の内容は, 日本運動生理学会学会誌「運動 生理学雑誌」に総説としてより詳細に記載される ので，興味のある方はそちらも併せて参照された い.

\section{引周立被}

1) Ashby, P., Verrier, M. and Lightfoot, E. (1974) Segmental reflex pathway in spinal shock and spinal spasticity in man. J. Neurol. Neurosurg. Psychiat. 37: 1352-1360.

2) Boorman, G., Hullinger, M., Lee, R. G., Tako, T. and Tanaka, R. (1991) Reciprocal Ia inhibition in patients with spinal spasticity. Neurosci. Lett. 127: 57-60.

3) Burke, D. (1983) Critical examination of the case for or against fusimotor involvement in disorders of muscle tone. Adv. Neurol. 39: 133-150.

4) Casabona, A., Polizzi, M. and Perciavalle, V. (1990) Difference in H-reflex between athletes trained for explosive contractions and non-trained subjects. Eur. J. Appl. Physiol. 61: 26-32.

5) Capaday, C. and Stein, R. B. (1986) Amplitude modulation of the soleus H-reflex in the human during walking and standing. J. Neurosci. 6: 13081313.

6) Capaday, C. and Stein, R. B. (1987) Difference in the amplitude of the soleus H-reflex during walking and running. J. Physiol. 382: 513-522.

7) Cowan, J. M. A., Day, B. L., Marsden, C. and Rothwell, J. C. (1986) The effect of percutaneous motor cortex stimulation on $\mathrm{H}$ reflexes in muscle of the arm and leg in intact man. J. Physiol. 377: 
333-347.

8) Crone, C. and Nielsen, J. (1989) Spinal mechanisms in man contributing to reciprocal inhibition during voluntary dorsiflexion of the foot. J. Physiol. 416: 255-272.

9) Crone, C., Hultborn, H., Maziéres, L., Nielsen, J. and Pierrot-Deseilligny, E. (1990) Sensitivity of monosynaptic test reflex to facilitation and inhibition as a function of the test reflex size : a study in man and the cat. Exp. Brain. Res. 81: 35-34.

10) Crone, C. (1993) Reciprocal inhibition in man. Danish Medical Bulletin 40: 571-581.

11) Delwaide, P. J. (1993) Pathophysiological mechanisms of spasticity at the spinal coad level. Spasticity : mechanisms and management. (Eds. Thilmann, A. F., Burke, D. J. and Rymer, W. Z.) Springer Verlag, pp.296-308.

12) Faist, M., Mazevet, V., Diets, V. and PierrotDesseilligny, E. (1996) A quantitative assessment of presynaptic inhibition of Ia affetrent in spastics, Difference in hemiplegics and paraplegics. Brain 117: 1449-1455.

13) Fournier, E., Meunier, S., Pierrot-Deseilligny, E. and Shindo, M. (1986) Evidence for interneuronally mediated Ia excitatory effects to human quadriceps motoneurones. J. Physiol. 377: 143-169.

14) Funase, K., Imanaka, K., Nishihira, Y. and Araki, H. (1994) Threshold of the soleus H-reflex is less sensitive to the change in excitability of the motoneuron pool during plantarflexion or dorsiflexion in man. Eur. J. Appl. Physiol. 69: 21-25.

15) Funase, K., Imanaka, K. and Nishihira, Y. (1994) Excitability of the soleus motoneuron pool revealed by the developmental slope of the $H$ reflex as reflex gain. Electromyogr. Clin. Neurophysiol. 34: 477-489.

16) Funase, K, Imanaka, $K$ and Nishihira, $Y$. (1996) Inhibition of the soleus H-reflex during dorsiflexion is dependent on individual differences in maximal soleus H-reflex as a test reflex. Percept. Motor Skills 82: 403-410.

17) Funase, K, Higashi, T., Yoshimura, T., Imanaka, K. and Nishihira, Y. (1996) Evident differencein the excitability of the motoneuron pool between normal subjects andpatientswith spasticity assessed by a new method using H-reflex and Mresponse. Neurosci. Lett. 203: 127-130.
18) Funase, K., Imanaka, K., Nishihira, Y., Higashi, T., Yoshimura, T. and Araki, H. (1996) Soleus motoneuron pool excitability in the resting state affects the amount of reciprocal inhibition during dorsiflexion. Adv. Exerc. Sports Physiol. 2: 65-72.

19) Funase, K., Higashi, T., Imanaka, K. and Nishihira, Y. (1998) Inter-individual differences of motoneuron pool excitabiity assessed by H-reflx are associated with the presynaptic inhibition of Ia afferents. Adv. Exerc. Sports Physiol. 4: 71-75.

20）船瀬広三・東登志夫・榊原淳（2001）座位およ び立位における下肢筋と上肢筋の $\mathrm{H}$ 反射について. 日本運動生理学／日本バイオメカニクス学会合同 学会大会大阪 2000 論集 p.282.

21) Goulart, F., Valls-Solé, J. and Alvares, R. (2000) Posture-related changes of soleus H-reflex excitability. Muscle \& Nerve 23: 925-935.

22) Hagbarth, K. E., Wallen, G. and Lofstedt, L. (1975) Muscle spindle responses to stretch in normal and spastic subjects. Scand. J. Rehabil. Med. 5: 156-159.

23) Higashi, T., Funase, K, Kusano, K., Tabira, T., Harada, N., Sakakibara, A. and Yoshimura, T. (2001) Motoneuron excitability of the hemiplegic patients and their stage of recovery from spasticity assessed by the Hslp/Mslp. Arch. Physical Med. Rehabilitation, in press

24) Kayser, B., Bokenkamp, R. and Binzoni, T. (1993) Alpha-motoneuron excitability at high altitude. Eur. J. Appl. Physiol. 66: 1-4.

25) Katz, R., Meunier, S. and Pierrot-Deseilligny, E. (1989) Changes in presynaptic inhibition of Ia fibres in man while standing. Brain 111: 417-437,

26) Koelman, J. H. T. M., Bour, L. J., Hilgevoord, A. A. J., van Bruggen, G. J. and Ongerboer de Visser, B. W. (1993) Soleus H-reflex tests and clinical signs of the upper motorneuron syndrome. J. Neuro. Neurosurg. Psychiatr. 56: 776-781.

27) Levin, M. F. and Hui-Chan, C. (1993) Are H and stretch reflexes in hemiparesis reproducible and correlated with spasticity? J. Neurol. 240: 63-71.

28) Meinck, H. (1980) Facilitation and inhibition of the human $\mathrm{H}$ reflex as a function of the amplitude of the control reflex. Electroenceph. Clin. Neurophysiol. 48: 203-211.

29) Mendell, L. M. and Henneman, L. (1971) Terminals of single Ia fibers : Location, density, 
and distribution within a pool of 300 homonymous motoneurons. J. Neurophysiol. 34: 171-184.

30) Milanov, I. (1992) A comparative study of methods for estimation of presynaptic inhibition. J. Neurology. 239: 287-292

31) Milner-Brown, S., Girvin, J. P. and Brown, W. F. (1975) The effects of motor cortical stimulation on the excitability of spinal motoneurones in man. Can. J. Neurologi. Sci. 2: 245-253.

32) Mizuno, Y., Tanaka, R. and Yanagisawa, N. (1971) Reciprocal group I inhibition on triceps surae motoneuron in man. J. Neurophysiol. 34: 1010-1017.

33) Nielsen, J., Crone $C$ and Hultborn $H$ (1993) $H$ reflex are smaller in dancers from The Royal Danish Ballet than well-trained athletes. Eur. J. Appl. Physiol. 66: 116-121.

34) Nielsen. J., Petersen. N. and Crone. C. (1995) Changes in transmission across synapses of Ia afferents in spastic patients. Brain 118: 995-1004.

35) Rothwell, J. C., Day, B. L., Berardelli, A. and Marsden, C. (1984) Effects of motor cortex stimulation on spinal interneurones in intact man. Exp. Brain Res. 54: 382-384.

36) Shindo, M., Harayama, H., Kondo, K., Yanagisawa, N. and Tanaka, R. (1984) Changes in reciprocal Ia inhibition during voluntary contraction in man. Exp. Brain Res. 53: 400-408.

37）進藤正臣（1990）髄節性機能とその中枢性調節.
日猡医報 35 ：180-192.

38) Schieppati, M. (1987) The Hoffmann reflex : A means of assessing spinal reflex excitability and its descending control in man. Prog. in Neurobiol. 28: 345-376.

39) Tanaka, R. (1974) Reciprocal inihibition during voluntary movements in man. Exp. Brain Res. 21: 529-540.

40）田中捱作（1986）H反射一ヒトにおける神経生 理学研究の一技法. 日本生理学雑誌 $48 ： 719-734$.

41）田中硧作（1989）随意運動制御の脊㖪神経機構. 神経科学レビュー3 医学書院, pp.61-91.

42）田中崕作 (1995) 痙縮の神経機構?再訪. リ八 ビリテーション医学. $32: 97-105$.

43) Valls-Sole, J., Alvarez, R. and Tolosa, E. D. (1994) Vibration-inducedpresynaptic inhibition of the soleus $\mathrm{H}$ reflex is temporarily reduced by cortical magnetic stimulation in human subject. Neurosci. Lett. 170: 149-152.

44) Willer, J. C., Miserrocchi, G. and Gautier, H. (1987) Hypoxia and monosynaptic reflexes in humans. J. Appl. Physiol. 63: 639-645.

45) Wolpaw, J. R. and Carp, J. S. (1997) Memory trace in spinal cord. Trends in Neurosci. 13: 137142 . 